\title{
Influence of Social Media in Application of Redgram Production (Cajanus cajan L. millsp.) Technologies in Bidar District of Karnataka, India
}

\author{
Mohd Riyaz $^{1}$, D. Raghupathi ${ }^{2 *}$ and M. Venkatesh ${ }^{3}$ \\ ${ }^{1}$ Department of Agricultural Extension, GKVK, University of Agricultural Sciences \\ Bangalore, India \\ ${ }^{2}$ Directorate of Extension, ZARS VC Farm Mandya, Karnataka, India \\ ${ }^{3}$ Department of Horticulture, College of Agriculture, VC Farm Mandya, Karnataka, India \\ *Corresponding author
}

\section{A B S T R A C T}

\section{Ke y w o r ds \\ Social media, Internet web sites, \\ Pulse bowl of \\ Karnataka, \\ Application of \\ technologies, \\ University \\ production \\ technologies \\ Article Info \\ Accepted: \\ 04 March 2020 \\ Available Online: \\ 10 April 2020}

The social media platforms provide wide open access to the pool of agricultural information for all the food value chain players and customers. In case of farmers, it is catering the information service for their awareness and knowledge gain with timely updates, at minimal cost, reaching and linking with large number of supply - marketing chain players across the globe. In this regard, the research study was conducted in Bidar district of Karnataka State, with an objective of finding out extent of usage of social media by the Redgram growers in gaining knowledge and application of farm university technologies to increase crop yield. The study found that, majority of the respondents did not use the social media platform for information seeking and its application and a few of them used it for general purpose and very less for agricultural learning purpose. Further, the study attempted to trace the association of social media usage with the grain yield production, it is found that there was non significant association between them inferring, the social media did not influence significantly in increasing the grain production among the growers.

\section{Introduction}

Use of social media has become indispensible social order in day-today-life of people across the globe, either for entertainment, trade, agriculture improvement. Almost every individual is owning cell phone in India. They are availing the advantage of inbuilt software platforms available along with smart phone gadgets purchase for free access. The important social media platforms are WhatsApp, SMS, YouTube, Facebook, Twitter etc, along with the popular mass media; News paper dailies, Radio and Television channels. The latter ones usage has been reducing with the onset of social media emergence. Where in the print media is like 'rather than being buried within the pages of a newspaper or magazine, platforms such as Twitter and Face book will make sure 
messages will not go unnoticed in their circle of influence, particularly if you manage to go viral. Social media will also allow Agribusinesses to see any current news regarding their audience and other farmers which could give them a competitive edge they previously didn't have. Since the growth of social media in agriculture, audiences have been interacting more and displaying their curiosity in the industry (Ben Watts, 2018).

The ICAR, Farm universities, Cooperatives, Input agencies have been disseminating the farm production technologies and marketing information through the uploaded portals. A flood of information is available from seed to harvest, post harvest and marketing for the farmers in the agricultural portals, which have been designed and developed in a way that the portals are user friendly at free of cost; to access it, it requires computer functional literacy. The ICT social media is delivering the information speedily, timely and guiding the other sources of information required. It is catering a complimentary role of field function functionaries of Department of Agriculture and Farm Universities in India. There is pressing demand for pulses to address nutritional requirements especially among the women and children. Therefore, more production is required. There is a potential scope to double the productivity of Redgram (Cajanus cajan L) from 7.60 to 15.0 $\mathrm{q} /$ ha provided the farmers apply the recommended technology of farm universities under rainfed condition. Such conditions was largely prevailing in the North-East Karnataka region, the Kalaburgi and Bidar districts known to be "Pulse bowl of Karnataka". Hence the study was conducted in Bidar district during 2017-18. The objectives of the study were to find out the extent of social media usage by the Redgram growers and its influence in application of recommended production technologies for grain production.

\section{Materials and Methods}

The research study was undertaken in Bidar district of Karnataka. Which consists of five taluks, out of these three taluks namely Aurad, Bhalki and Basavakalyan were selected by considering the large area under Redgram cultivation. The respondents were selected by adopting, statistical random sampling procedure. The sample size was 120 (Fig. 1).

The Research design adopted was Ex-post facto research, exploratory type was used (Kerlinger, 1973). Alternate hypothesis: The is a association between social media usage and application of recommended production technologies among the Redgram growers. Operational definition of Variables and their measurement: One independent and one dependent variable were selected. The independent variable is social media usage, the dependent variable is application of recommended production technologies. The 'social media usage' refers to the how frequently the respondents used the social media platforms such as whatsApp, YouTube, Facebook etc., for information seeking related to Redgram production along with Newspaper dailies, Radio and Television. It was measured by assigning nominal score, 3 for More usage, 2 for Medium usage and 1 for Less usage on a three point continuum of regular, Occasional and Not. The maximum score possible was 33 and the minimum was 11. The total score obtained was categorised as More, Medium and Less.

The dependent variable 'extent of application of recommended technologies' refers to, application of technologies recommended by the farm universities It is measured by assigning nominal score, 3 for Full application, 2 for Partial application and 1 for Not application. There were 14 items of production technologies were listed on a three 
point continuum. Based on the obtained score the respondents were categorised in to Full extent, Partial application and Not applied. The procedure followed by Nagananda (2005) with slight modifications was used for empirical quantification of this variable.

\section{Developing interview schedule and data collection}

Considering the objectives of the study a structured interview schedule was prepared, pre-tested in non-sample area and modifications were incorporated. An apparent of content validity of all the items was ensured before the interview schedule was finalized. The data were collected from the selected respondents visiting the villages of the Bidar district during 2017-18. The interview schedule was administered to the respondents and oral information and opinion expressed by oral and from memory was documented. The visual observations were made accordingly. While collecting information care was taken to avoid onlookers' influence and group pressure on the respondent to ensure pertinent information. The Participatory Rural Appraisal tools such as Focus Group Discussions and Transact walk were also used to supplement the data wherever required. The secondary sources like, reports and records were referred from the developmental departments. For analyzing the data, the statistical tools frequency, percentage, mean, standard deviation were used and to find out association between independent variables and dependent variable non-parametric 'Chi square' test was used to draw an inference.

\section{Results and Discussion}

\section{Extent usage of social media}

Majority of the respondents did not use the media (News paper, Radio, TV and Videos, $\mathrm{CDs}$ ) for general and agriculture purpose. A few of them $(>10 \%)$ used regularly for nonagricultural purposes. In case of social media (WhatsApp, Facebook, YouTube, SMS, Internet) Majority of them used for general (entertainment, News etc.) purpose and less for agriculture purpose. On an average 5 per cent of the respondents used regularly, 35 per cent occasionally and 67 per cent not used them (Table 1). Further, extent of usage, majority of them were in the category of less extent usage of social media for agricultural purpose (Table 2). The reason could be lack of skills in using the social media plot forms and unaware of agricultural portals available in the internet sites.

Regarding application of recommended technologies of production, majority of the respondents applied the technologies to the full extent and remaining respondents applied the technologies either partially or not applied them (Table 3 and Fig. 3). The reasons for full applications could be, simple and low cost technologies which does not require social media accessibility.

Association between social media and extent of application of Redgram production technologies: There was a non-significant association between social media usage and application of technologies this implies that the social media had not influenced in application significantly (Table 4). Thus the alternate hypothesis set for the study is rejected and null hypothesis of no influence is accepted. The plausible reason could be less social media usage for Redgram production very less, might be they were not aware of agriculture technologies information availability and its accessibility. The findings are in confirmation (Prakash, 2000) and other reviews revealed that the media brings awareness and to some extent knowledge gain but not three application of technologies just by seeing or listening to the social media (Fig. 2). 
Table.1 Distribution of respondents regarding extent of social media participation $(n=120)$

\begin{tabular}{|c|c|c|c|c|c|c|c|c|c|}
\hline \multirow{3}{*}{$\begin{array}{l}\text { Sl. } \\
\text { No }\end{array}$} & \multirow[t]{3}{*}{ Media Sources } & \multicolumn{8}{|c|}{ Frequency of use } \\
\hline & & \multicolumn{2}{|c|}{ Regular } & \multicolumn{2}{|c|}{ Occasionally } & \multicolumn{2}{|c|}{ Not } & \multicolumn{2}{|c|}{ Total } \\
\hline & & No & $\%$ & No & $\%$ & No & $\%$ & No & $\%$ \\
\hline \multirow[t]{3}{*}{1} & \multicolumn{9}{|l|}{ News paper dailies } \\
\hline & General & 10 & 8 & 88 & 73 & 22 & 18 & 120 & 100 \\
\hline & Agriculture & 2 & 1 & 38 & 32 & 80 & 67 & 120 & 100 \\
\hline \multirow[t]{3}{*}{2} & \multicolumn{9}{|l|}{ Radio } \\
\hline & General & 10 & 8 & 35 & 29 & 75 & 63 & 120 & 100 \\
\hline & Agriculture & 5 & 3 & 25 & 21 & 90 & 75 & 120 & 100 \\
\hline \multirow[t]{3}{*}{3} & \multicolumn{9}{|l|}{ Television } \\
\hline & General & 10 & 8 & 105 & 88 & 5 & 4 & 120 & 100 \\
\hline & Agriculture & 0 & 0 & 1 & 1 & 119 & 99 & 120 & 100 \\
\hline \multirow[t]{3}{*}{4} & \multicolumn{9}{|l|}{ CD Videos } \\
\hline & General & 0 & 0 & 4 & 3 & 116 & 97 & 120 & 100 \\
\hline & Agriculture & 0 & 0 & 1 & 1 & 119 & 99 & 120 & 100 \\
\hline \multirow[t]{3}{*}{5} & \multicolumn{9}{|l|}{ WhatsApp } \\
\hline & General & 8 & 6 & 88 & 73 & 24 & 20 & 120 & 100 \\
\hline & Agriculture & 0 & 0 & 1 & 1 & 119 & 99 & 120 & 100 \\
\hline \multirow[t]{3}{*}{6} & \multicolumn{9}{|l|}{ Facebook } \\
\hline & General & 11 & 9 & 56 & 47 & 53 & 44 & 120 & 100 \\
\hline & Agriculture & 0 & 0 & 2 & 1 & 118 & 98 & 120 & 100 \\
\hline \multirow[t]{3}{*}{7} & \multicolumn{9}{|l|}{ YouTube } \\
\hline & General & 9 & 0 & 93 & 78 & 18 & 15 & 120 & 100 \\
\hline & Agriculture & 2 & I & 3 & 2 & 115 & 96 & 120 & 100 \\
\hline \multirow[t]{3}{*}{8} & \multicolumn{9}{|l|}{ SMS } \\
\hline & General & 5 & 3 & 70 & 58 & 45 & 38 & 120 & 100 \\
\hline & Agriculture & 0 & 0 & 3 & 2 & 117 & 98 & 120 & 100 \\
\hline \multirow[t]{4}{*}{9} & \multicolumn{9}{|l|}{ Internet } \\
\hline & General & 10 & 8 & 25 & 21 & 85 & 71 & 120 & 100 \\
\hline & Agriculture & 2 & 1 & 4 & 3 & 114 & 96 & 120 & 100 \\
\hline & Total & 84 & - & 642 & - & 1434 & - & 2160 & - \\
\hline \multicolumn{2}{|c|}{ Mean } & 5 & 4 & 35 & 29 & 80 & 67 & 120 & 100 \\
\hline
\end{tabular}

Table.2 Categorization of extent of social media usage $n=120$

\begin{tabular}{|l|l|c|c|}
\hline Sl. No & Category & f & \% \\
\hline $\mathbf{1}$ & More & 12 & 10.0 \\
\hline $\mathbf{2}$ & Medium & 07 & 6.0 \\
\hline $\mathbf{3}$ & Less & 101 & 84.0 \\
\hline & Total & $\mathbf{1 2 0}$ & $\mathbf{1 0 0 . 0}$ \\
\hline
\end{tabular}


Table.3 Technology application in Redgram cultivation (practice wise) of production $(n=120)$

\begin{tabular}{|c|c|c|c|c|}
\hline $\begin{array}{l}\text { Sl. } \\
\text { No. }\end{array}$ & production Practices & $\begin{array}{l}\text { Full } \\
\text { application } \\
(\%)\end{array}$ & $\begin{array}{l}\text { Partial } \\
\text { application }(\%)\end{array}$ & $\begin{array}{l}\text { Not applied } \\
(\%)\end{array}$ \\
\hline 1 & $\begin{array}{l}\text { Preparatory tillage (Deep ploughing and } \\
\text { pulverising the soil) }\end{array}$ & $120(100.00)$ & 0.00 & 0.00 \\
\hline 2 & $\begin{array}{l}\text { Recommended varieties (Hyd-3C, TTB-7, ICP- } \\
\text { 7035, BRG-1,2,4,5. }\end{array}$ & $102(85.00)$ & 0.00 & $18(15.00)$ \\
\hline 3 & Sowing time & $96(80.00)$ & 0.00 & $24(20.00)$ \\
\hline 4 & $\begin{array}{l}\text { FYM/Compost application (3tons/ha with } \\
\text { Trichoderma sp). }\end{array}$ & $38(32.00)$ & $50(42.00)$ & $32(26.00)$ \\
\hline 5 & Seed rate $(15 \mathrm{kgs} / \mathrm{ha})$ & $43(36.00)$ & $77(64.00)^{*}$ & 0.00 \\
\hline 6 & $\begin{array}{l}\text { Seed treatment (Sodium molybdate with melted } \\
\text { jiggery solution \& biofertilisers, Rhizobium and } \\
\text { PSB). }\end{array}$ & $43(30.00)$ & 0.00 & $77(70.00)$ \\
\hline 7 & Spacing $(60 \times 20 \mathrm{~cm})$ & $28(23.00)$ & 0.00 & $92(77.00)$ \\
\hline 8 & Transplanting (Dibbling) & $22(18.00)$ & 0.00 & $98(82.00)$ \\
\hline 9 & Use of Fertilizers (25-50-25kg NPK/ha) & 0.00 & $115(96.00)$ & $5(4.00)$ \\
\hline 10 & $\begin{array}{l}\text { Irrigation (protective irrigation twice flower and } \\
\text { pod stages) }\end{array}$ & $28(23.00)$ & 0.00 & $92(77.00)$ \\
\hline 11 & Nipping operation & $30(25.00)$ & 0.00 & $90(75.00)$ \\
\hline 12 & $\begin{array}{l}\text { Herbicides application (Pendimethalin 1day } \\
\text { after sowing) }\end{array}$ & $16(13.00)$ & 0.00 & $104(87.00)$ \\
\hline 13 & Plant protection measures (IPM) & $6(5.00)$ & $65(54.00)$ & $49(41.00)$ \\
\hline 14 & $\begin{array}{l}\text { Harvesting \& Threshing using small machines } \\
\text { (Tools and Small machines) }\end{array}$ & $98(82.00)$ & $10(8.00)$ & $12(10.00)$ \\
\hline & Total responses & 670 & 317 & 693 \\
\hline \multicolumn{2}{|c|}{ Score (continuum) assigned } & 3 & 2 & 1 \\
\hline \multicolumn{2}{|c|}{ \% Application } & 60.20 & 19.00 & 20.80 \\
\hline
\end{tabular}

*Applied more than the recommended (6 to 10kgs/ac).

Table.4 Association between Social media usage and application of production technologies

\begin{tabular}{|c|c|c|c|c|c|c|}
\hline \multirow[t]{2}{*}{$\begin{array}{l}\text { Extent usage of } \\
\text { Social media }\end{array}$} & \multicolumn{4}{|c|}{$\begin{array}{l}\text { Extent of application of recommended } \\
\text { technologies }\end{array}$} & \multirow[t]{2}{*}{$\%$} & Chi square value \\
\hline & Full & Partial & No & Total & & \multirow{5}{*}{$0.287 \mathrm{NS}$} \\
\hline More & 6 & 6 & 5 & 17 & 14.0 & \\
\hline Medium & 6 & 9 & 5 & 20 & 17.0 & \\
\hline Less & 60 & 9 & 14 & 83 & 69.0 & \\
\hline Total & 72 & 24 & 24 & 120 & 100.0 & \\
\hline$\%$ & 60.0 & 20.0 & 20.0 & - & 100.0 & - \\
\hline
\end{tabular}

NS: Non significant association 
Fig.1 Research study area

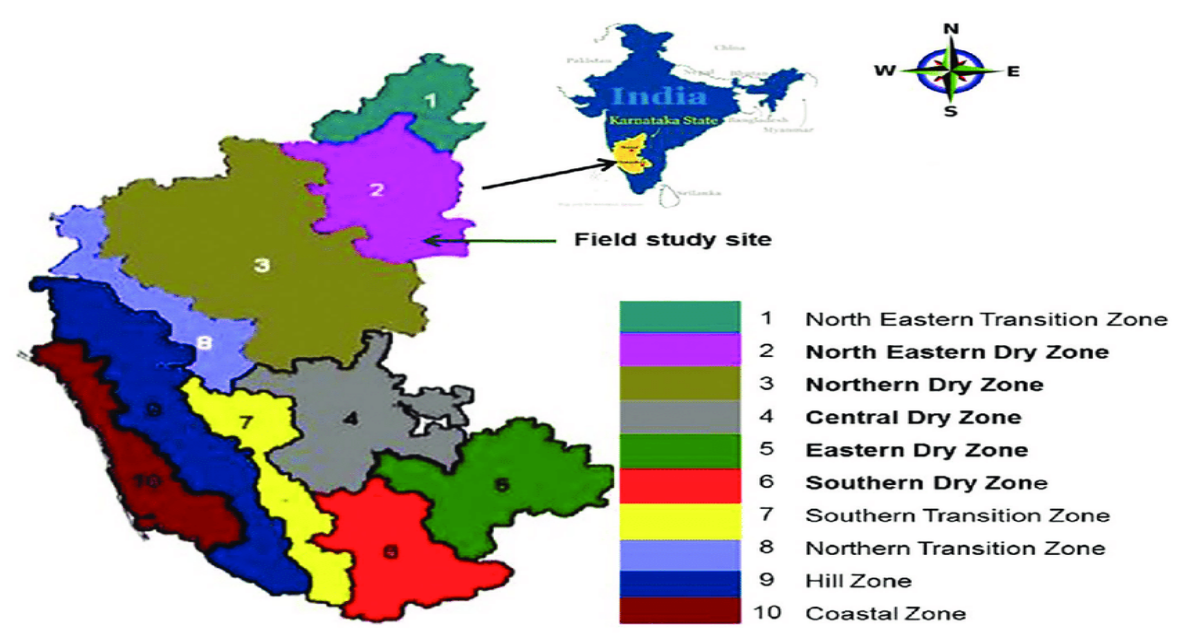

Source: Census India 2011

Fig.2 Extent of social media usage by the respondents

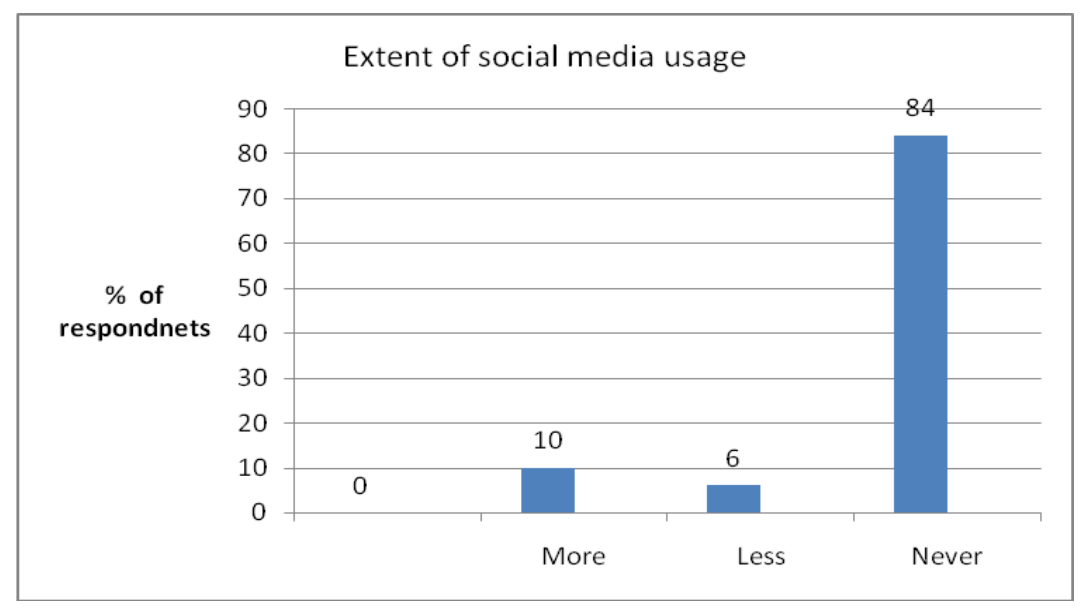

Fig.3 Extent of gap in technological application, Redgram cultivation practices

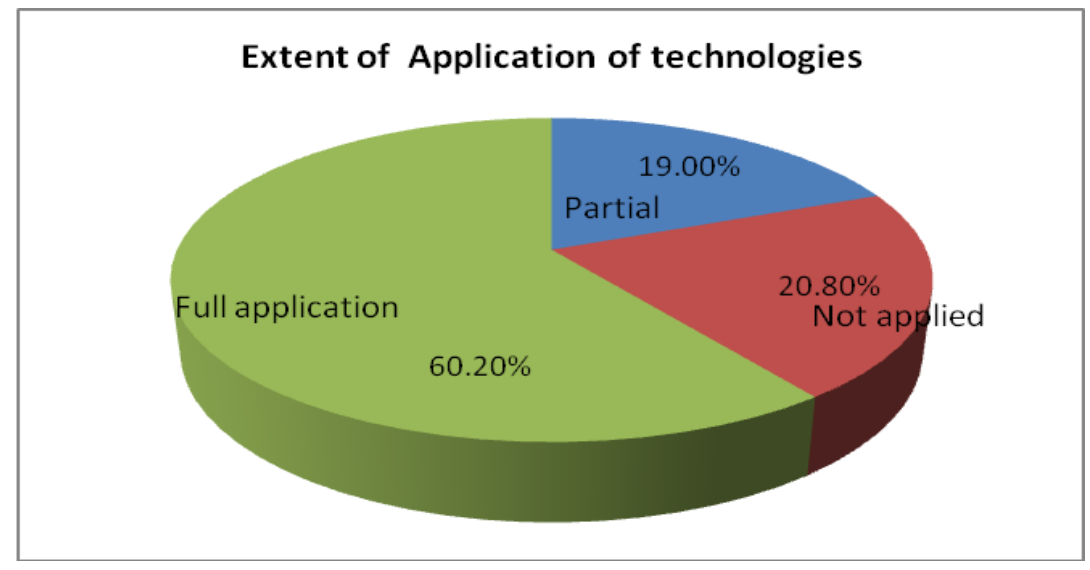


To conclude, the research study found that the extent of social media was less and the majority of them did not use them for agricultural purpose. Majority of the respondents did not use the social media for general as well as agricultural purpose. Majority of the respondents applied the recommended technologies to the full extent might not be because of social media usage. The remaining practices were either partially applied and fully applied based on their socioeconomic and psychological orientations. The extent of social media usage was less because of lack of skills in usage, leas computer literacy and unaware of agricultural portals in the internet sites and their accessibility. Further there was no significant association between social media usage and the application of production technologies. This implies that, whatever the little social media was used was for general purpose, may be for entertainment, not for completely for seeking and application of technologies for increasing Redgram productivity. The implications of the study being empower the farmers with social media usage skills and awareness about the availability of agricultural portals in the internet sites.

\section{Acknowledgement}

I acknowledge the support given by esteemed University for the opportunity to guide the M.Sc. student. I also thank the advisory committee members in guiding the students and completion of his M.Sc program successfully. Finally I express gratitude to the farmers for giving their valuable information in compilation of data and findings.

\section{References}

Aagropedia.com ICAR Portal, Indian Council of Agricultural Research, Government of India.

Ben Watts., 2018,

Https://www.challenge.org/knowledgeit ems/the-influence-of-social- media-inagriculture/ The influence of social media in agriculture.

Bite Bhalchandra Balkrishna and Anand A Deshmukh 2017, A Study on Role of Social Media in Agriculture Marketing and its Scope Global Journal of Management and Business Research: E Marketing. 17(1).

Devesh Thakur and 2 Mahesh Chander, 2016, The World Development Report, use of social media in agricultural extension: some evidences from India, Division of Extension Education, Indian Veterinary Research Institute, Izatnagar, Bareilly UP India.

GoK 2015, Government of Karnataka, Report on Area, Production \& Productivity and prices of Agricultural crops in Karnataka, DES No.9:11.

FAO 2016, www.fao.org/pulsses-2016

Indiastat.com/agriculture-data/2/agriculturalproduction

Kerlinger, F. N., 1973, Foundations of Behavioural Research. Holt Rinehart and Winston Inc., New York.

National Institute of Agricultural Extension Management (MANAGE) 2017Social media for agricultural extension Bulletin, Rajendranagar, Hyderabad 500 030, Telangana State, India.

Package of practices 2010, Directorate of Extension, University of Agricultural Sciences Bangalore, Karnataka: 123131

Prakash, P., 2000, A study on the technological gap, grain yield gap and constraints of paddy cultivation in Palakkad district of Kerala. M. Sc. (Agri.) Thesis, University of agricultural sciences, Bangalore, Karnataka, India

UN report 2017, State of Food Security and Nutrition in the World. www.wfp.org/publications/2017-statefood

Wondangbeni, K., 2010, Adoption Gap in Groundnut Production in Northern Transition Zone of Karnataka. 


\section{How to cite this article:}

Mohd Riyaz, D. Raghupathi and Venkatesh, M. 2020. Influence of Social Media in Application of Redgram Production (Cajanus cajan L. millsp.) Technologies in Bidar District of Karnataka. Int.J.Curr.Microbiol.App.Sci. 9(04): 121-128.

doi: https://doi.org/10.20546/ijcmas.2020.904.016 